Bangladesh J. Plant Taxon. 27(2): 377-389, 2020 (December)

(C) 2020 Bangladesh Association of Plant Taxonomists

\title{
A STUDY ON WILD EDIBLE PLANTS FOR HUMAN CONSUMPTION IN HIZAN COUNTY OF BITLIS, TURKEY
}

\author{
IBRAHIM DEMIR* \\ Department of Biology, Faculty of Arts and Sciences, \\ Bitlis Eren University, Bitlis, Turkey.
}

Keywords: Bitlis; Hizan; Traditional uses; Turkey; Wild edible plants.

\begin{abstract}
This study covers the edible plants in Hizan where there is a rich culture of plant consumption. The study was conducted between 2018 and 2019 to record the culture of traditional food plant use of the local people in Hizan. In this regard, the face-to-face interviews with the local people were made, and the relevant plants used were collected and identified. A total of 65 species of wild edible plants belonging to 24 families were identified, and their different traditional usages were categorized as cooked, cheese making, rennet, specie and gum producing, and as raw or beverages etc. In addition, the use-value (VU) index was calculated for each species. The mostly used species included Rheum ribes L. (UV: 0.70), Gundelia tournefortii L. (0.66), Silene vulgaris (Moench) Garcke, Rosa canina L. (0.64), Urtica dioica L. (0.63), Malva neglecta Wallr. (0.61), and Pistacia khinjuk Stocks (0.60). The culture of edible plant use is widespread throughout the Anatolia. However, traditional uses of many wild plants have not been recorded yet. Therefore, this research will be an important contribution to the preservation of the cultural heritage associated with traditional wild edible plants in this region.
\end{abstract}

\section{Introduction}

Wild plants have had an important role in prehistoric communities which supplied their own food needs by hunting and gathering (Baytop, 1999). Since the early ages, human beings have utilized plants found in their region for different purposes. Human beings have learned to make use of plants as food over time and have continued their lives by passing this knowledge from generation to generation and have tended to obtain more efficient and quality products by making the cultivation of highly consumed plants (Urhan et al., 2016). However, only a part of the edible plant species found in nature have been cultivated. The number of species grown as food are around 3,000 while the number of wild plant species that have been used as food is over 10,000 (Baytop, 1999). Wild plants are the cheapest resource of nutrients, providing minerals, vitamins and essential fatty acids, enhancing taste and color in diets (Turan et al., 2003; Green, 1992; Bianco et al., 1998). These wild plants used as food can be grown as alternative crops in the future's agriculture and broadly used in human nutrition.

There are many evidences in Near Eastern regions relevant to the plant consumption of Neandertals (Madella et al., 2002; Henry et al., 2001). Plant products have always had a vital role in the Near East, they have been used as fuel, construction materials and medicines besides as food (Nesbitt, 1995).

In Anatolia, there has been a historical relationship between plant and human. Thus, a rich culture of wild plant use developed in Anatolia. Many wild edible plants that grow naturally, especially in eastern Anatolia, are gathered and consumed as food (Mükemre et al., 2016; Kaval et al., 2015; Polat et al., 2015). Hizan of Bitlis province is a county in eastern Anatolia which was

\footnotetext{
*Corresponding author, E-mail: hosap65@gmail.com
} 
a home to many civilizations (Çiçek, 2016). Hizan is also a prominent vegetation area surrounded by high mountains reaching an altitude of about $3000 \mathrm{~m}$ (Kılıç et al., 2016). Wild edible plants can be eaten freshly by public living in rural areas, as well as can be consumed as dry during hard winter periods. Along with urbanization, the culture of use of wild edible plants is reducing day by day. For this reason, it is very important that traditional knowledge of the plant use should be recorded before it disappears. This study aims to investigate and record the existing knowledge about wild plants used as food by the indigenous people residing in Hizan of Bitlis province of Turkey.

\section{Materials and Methods}

\section{Study area}

This research was carried out in the center of in the villages of Gayda, Aladana, Ürünveren, Akşar, Karbastı, Koçyiğit, Nurs, Sağınlı, Oymapınar, Ballı and Döküktaş (Kayaş) of Hizan district. Hizan is located in Eastern Anatolia Region and it is 1700 meter above average sea level. Hizan is neighbour to Gevaş and Bahçesaray (Van) in the east, Şirvan and Pervari (Siirt) in the south and Tatvan (Bitlis) in northwest (Fig. 1).

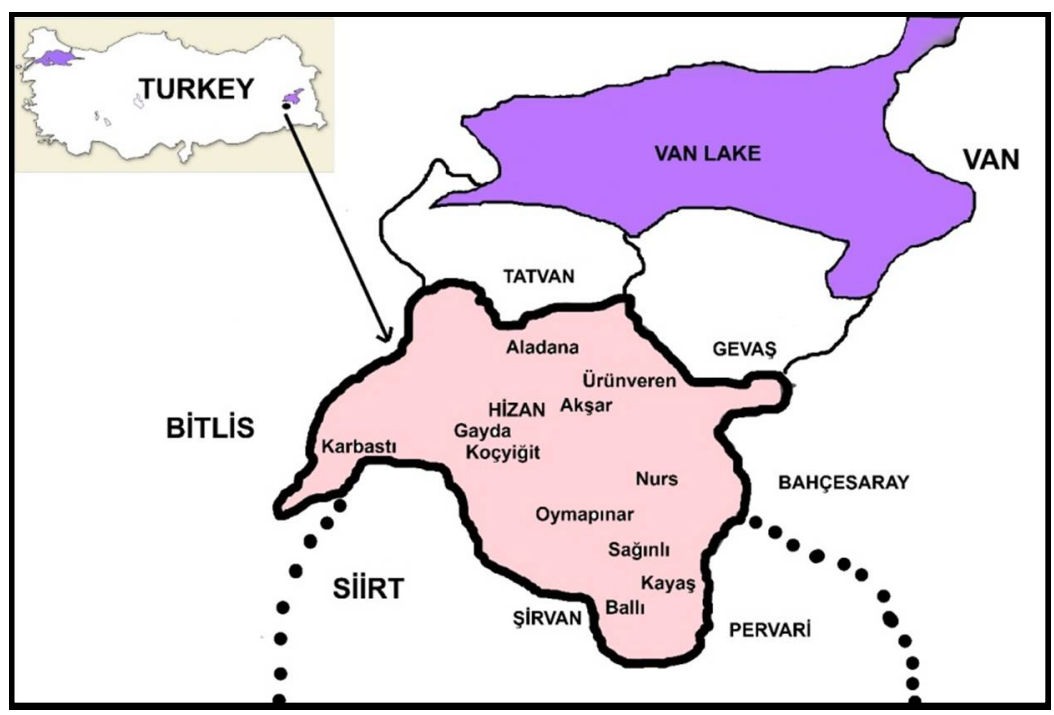

Fig. 1. Geographical location of the study area.

Hizan belongs to the Iran-Turan Plant Geography Region and falls within the B9 grid square according to the Grid classification system developed by Davis (Davis, 1965-1985). According to the results of address-based population census (https://biruni.tuik.gov.tr/ medas/? kn=95\& locale=tr) conducted in 2019, the total population of Hizan district is 33.331. The ethnic composition of the district consists of Kurdish people.

Hizan has been a center of civilization since the Hittites. According to historical records, human settlements are known to be present there from the 2000s BC. Human settlements started with the Hittites and continued under Persian, Roman, Byzantine and Arab rule. It was ruled by Seljuks in the $11^{\text {th }}$ century and by Ottomans period in the $16^{\text {th }}$ century. Urartians were probably the first state using the name of "Arart" that is encountered on the records as Hizan's first name. The 
name "Seherhizan", given later by the Persians, means "the wakeners in the dawn". This name, which was later shortened as "Hizan", has been recorded in history as "the place of the nation that wakens early" (Çiçek, 2016).

\section{Plant materials}

The field study was carried out over a period of approximately two years (2018-2019) and a total of 16 area studies were carried out in two years. During this period, plant materials were collected. The collected samples were prepared according to herbarium techniques, and stored in the Biology Department of Facultyof Arts and Sciences, Bitlis Eren University. Identification of plant taxa, was performed by using Flora of Turkey (Davis, 1965-1985; Güner et al., 2000; Davis et al., 1988). The scientific names of the plant samples were confirmed by using Web site of The Plant List (http://www.theplantlist.org). The taxonomic categories (family, species) of the identified samples were arranged in alphabetical order.

\section{Interviews with native people}

In 2018 and 2019, the face-to-face interviews were held with participants who have traditional knowledge and experience. The information was obtained through interviews with 110 people, including 62 women and 48 men. Interviews were mainly conducted with those who were more informative regarding the subject. The ethnic structure of the district consists of Kurds. Therefore, the interviews were in Kurdish. The questions on local name, parts of the plant used, and preparation procedure of the plant or plant part used were asked to the participants and the answers were recorded. In addition, information about the participants (name, surname, sex, age, education, job, etc.) were recorded. Participants generally live in rural areas, but some people usually live in the highlands on a seasonal basis.

\section{Calculations}

The use value (UV) index proposed by Phillips and Gentry (1993) has been widely used to quantify the relative importance of species.

The use value (VU) index was calculated for each species using the following Formula:

$\mathbf{U V}=\mathbf{U} / \mathbf{N}$

$\mathbf{U V}=$ the use value of a species,

$\mathbf{U}=$ the number of citations per species and $\mathbf{N}=$ the number of informants.

\section{Results and Discussion}

Taxonomic identification of wild edible plants

In this study, 65 taxa belonging to 24 families that are used as food were recorded from Hizan district (Bitlis). Most of these plants belong toApiaceae (14\%), followed by Asteraceae, Lamiaceae, Polygonaceae and Rosaceae (with 9\% each), Amaryllidaceae (8\%), Malvaceae (6\%), and Boraginaceae (5\%). The remaining plant families (total 31\%) are represented by only one or two species (Fig. 2). The plants were categorized into various groups on the basis of their use in Hizan. These uses included those plants that are consumed as cooked vegetables, used in cheese making, used as rennet, spices and gums, and consumed as raw (salads, etc.) or beverages (tea, coffee).

In this study, conducted in Hizan County (Bitlis) during 2018-2019, the recorded uses of wild plants as food are given in Table 1 under the headings-edible parts and utilization methods, with the information regarding family, scientific name, voucher number, and vernacular names (Kurdish). The largest use category was vegetables consumed by cooking with 29 taxa, followed by those consumed as raw (salads, etc.) with 16 taxa, used in cheese making with nine taxa, used 
as rennet with seven taxa, consumed seasonally with six taxa, and used as gums and beverages with four taxa each. But some species can be used for more than one purpose (such as Pistacia khinjuk used for making both coffee and cheese), thus 71 different uses have been determined.

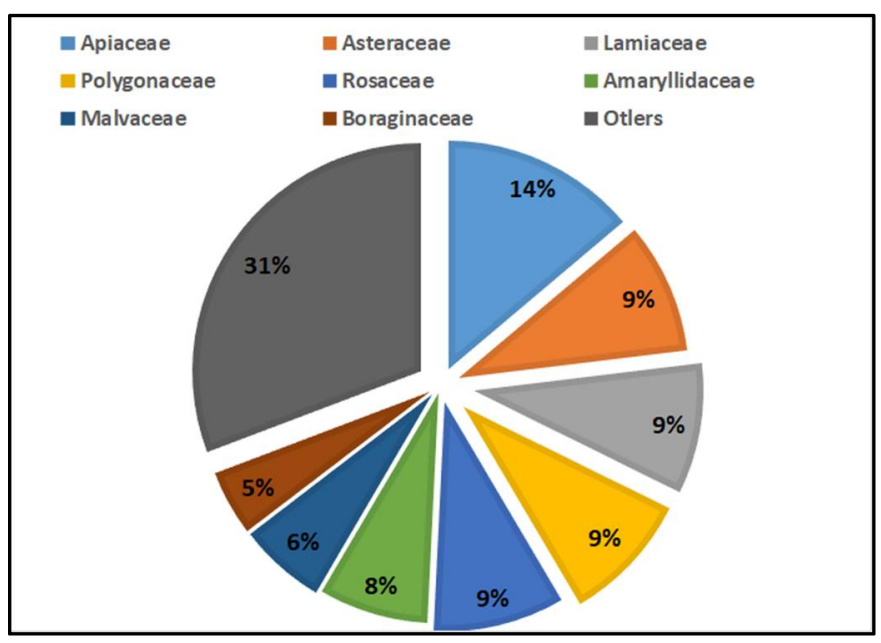

Fig. 2. The percentages of the used plant families

\section{The cooked plant consumption}

The largest category of wild edible plants used by local people in Hizan belongs to the cooked vegetables (29 taxa). This is consistent with the studies conducted in eastern Anatolia (Mükemre et al., 2016; Kaval et al., 2015; Polat et al., 2017; Özçelik 1994). The use of plants in this category generally very as they are widespread. It can be said that they can grow in almost every habitat (roadside, field etc.). However, most of these plants are harmful, i.e. perform as weed in agricultural areas (Tepe, 2014). In the spring, some taxa are freshly picked, boiled and drained, and then they are usually cooked with eggs, or eaten with yogurt (Centaurea solstitialis L., Anchusa azurea Miller, Chenopodium album L., Papaver clavatum Boiss. \& Hausskn. Ex Boiss. Rumex angustifolius subsp. macranthus (Boiss.) Rech. f., Malva neglecta Wallr., Eremurus spectabilisM. Biebetc.). Fresh leaves of some taxa are used as packaging material in "sarma" (Alcea flavovirens (Boiss. \&Buhse) Iljin, Alcea remotiflora (Boiss. \& Heldr.) Alef., Rumex tuberosus L. subsp. horizontalis (Koch.) Rech, Rumex patientia L.). Some are dried and stored. Some dried plants are consumed in pilaf or added to soup, especially in winter. (Allium akaka L., Arum rupicola Boiss, Puschkinia scilloides Adams, Silene vulgaris (Moench) Garcke, Satureja macrantha C.A. Mey. and Urtica dioica L.). The fresh shoots of the Gundelia tournefortii L. and Ferula orientalis L. species, which are widely consumed in Bitlis region, are picked and corned, and then stored for winter use.

\section{The plants used in cheese making}

There are extensive sheep and goat breeding in Hizan County. The milk of sheep and goats fed in high plateaus is generally used in cheese making, and edible wild plants are a part of this agricultural activity. The cheese made with various wild edible plants is called "herby cheese". Many taxa have been used in cheese production in Eastern Anatolia for centuries. In Turkey, herby cheese is produced only in the East Anatolian provinces: Van, Bitlis, Siirt, Hakkari, Bingöl and Tunceli (Özçelik, 1994). In spring, many taxa are collected from the high plateaus and added 


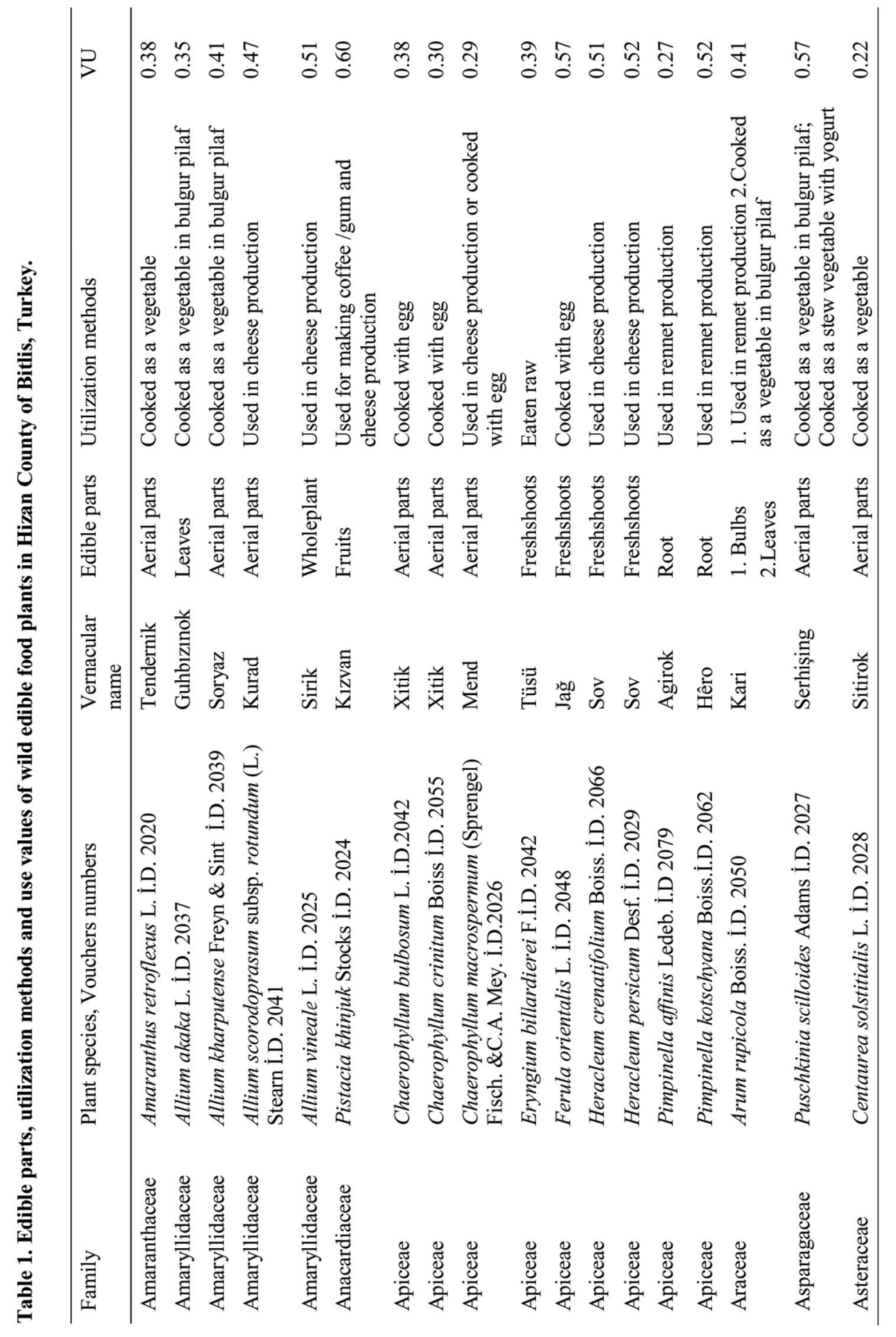




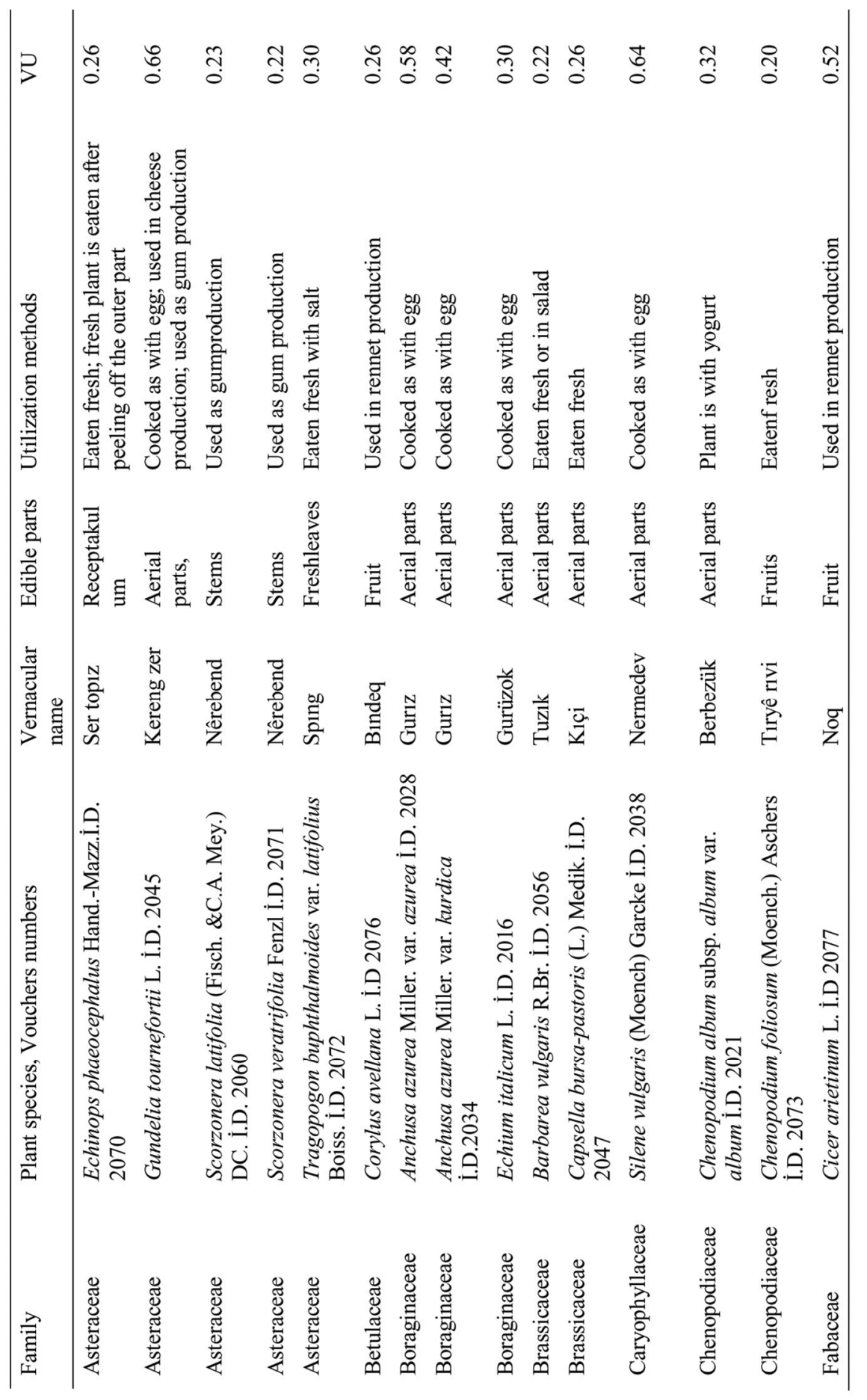




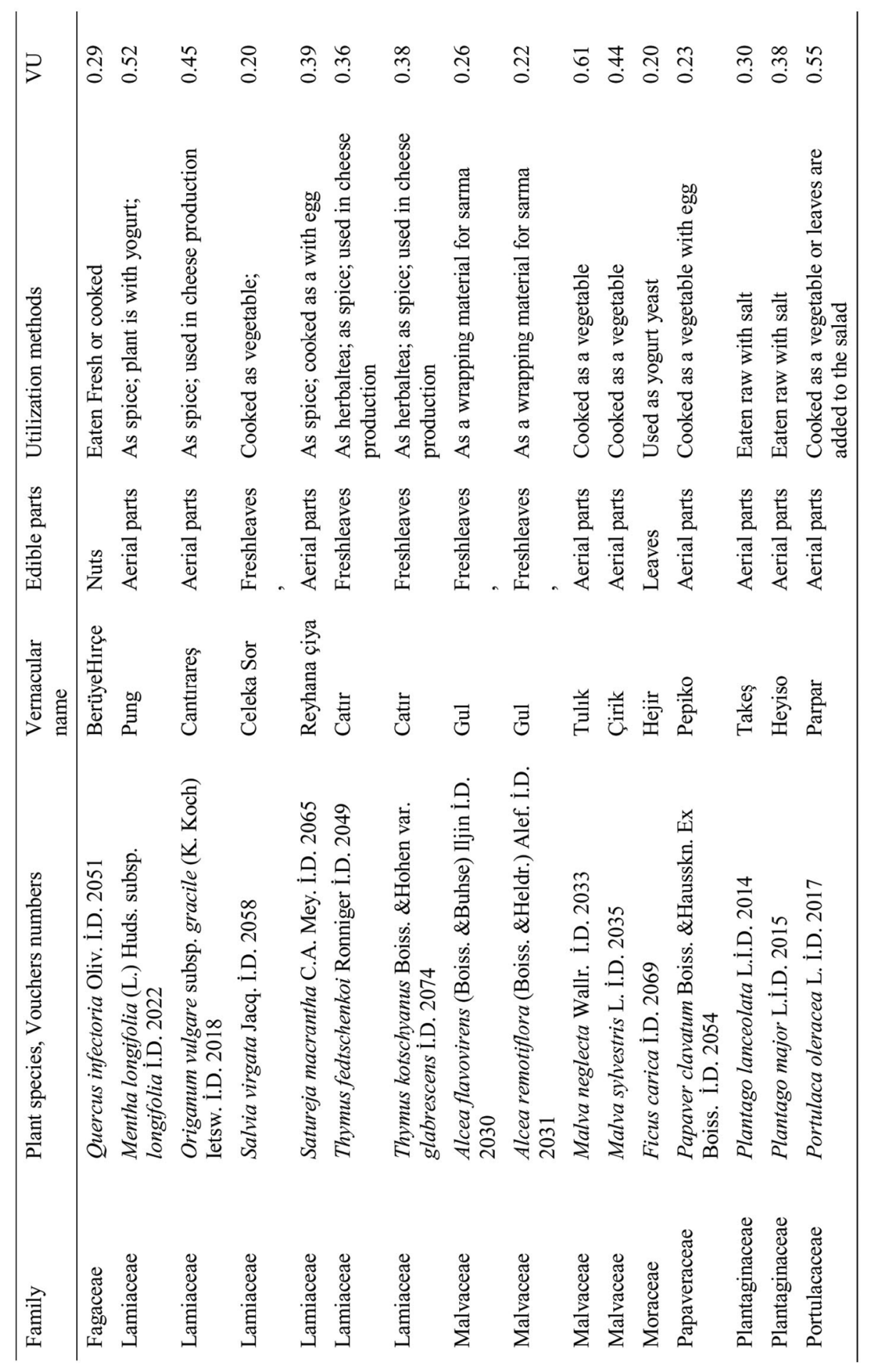




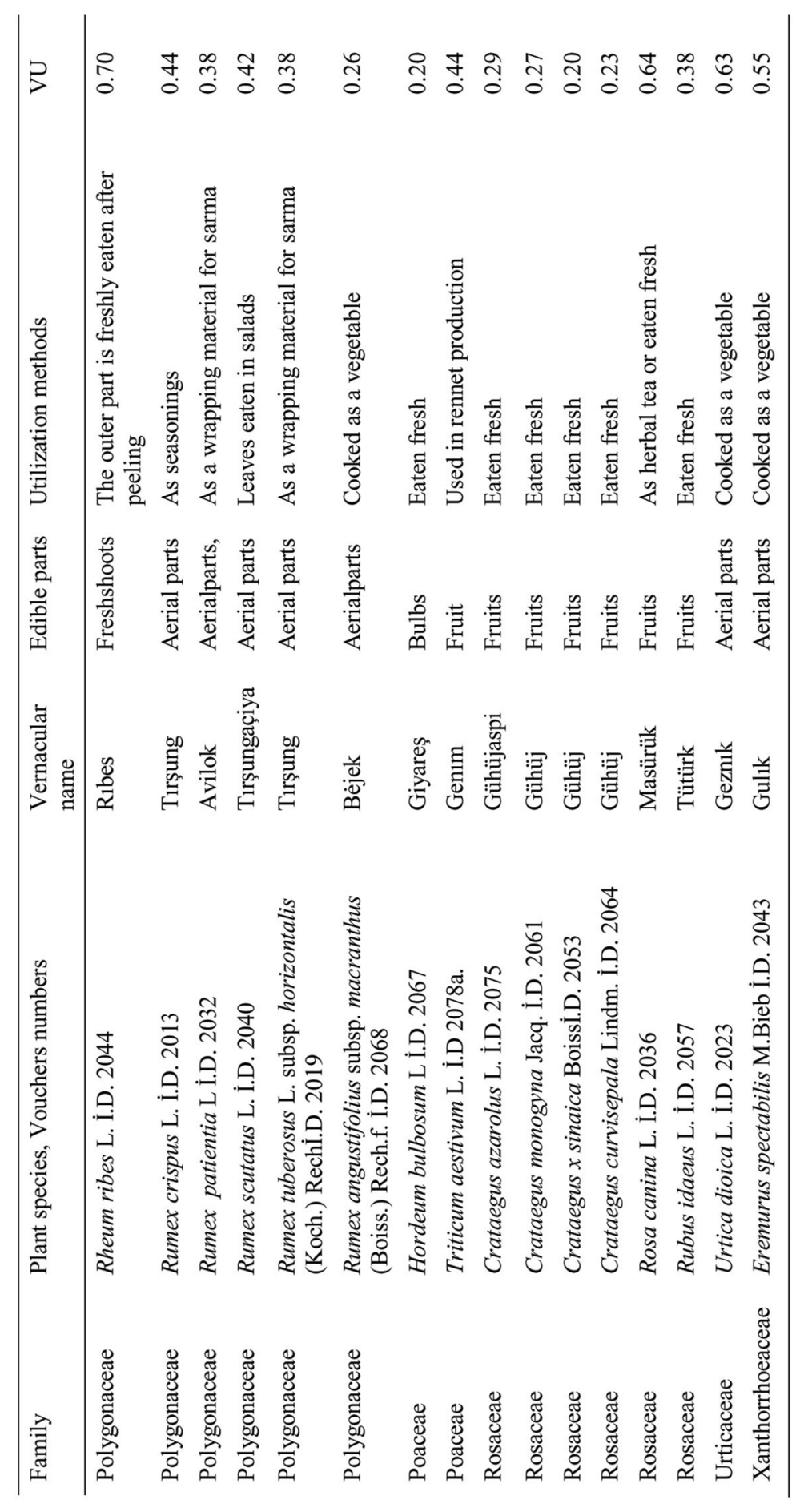


to cheese. The milk used in cheesemaking is not boiled. These plants are probably used for antibacterial and aroma agent. It is found that plants such as Allium vineale and Chaerophyllum macropodum used in cheese making had antibacterial activity against the Gram-positive and Gram-negative bacteria (Durmaz et al., 2006). Nine taxa have been identified in this category in study area. Allium scorodoprasum subsp. rotundum (L.) Stearn, A. vineale L., Pistacia khinjuk Stocks, Chaerophyllum macrospermum (Sprengel) Fisch. \& C.A. Mey., Heracleum crenatifolium Boiss. and $H$. persicum Desf. taxa are used in cheese making in Hizan county. However, fresh leaves of Origanum vulgare subsp. gracile (K. Koch) Ietsw., Thymus fedtschenkoi Ronniger, and Thymus kotschyanus Boiss. \& Hohen var. glabrescensare are chopped and used directly.

Those used as dairy products yeast

Intensive cheese production has concurrently brought out the need for rennet. In ancient times, people were making their own rennet themselves. The local people started to use commercial yeasts with the developments in transportation. However, the old method of making rennet in Hizan continues rarely (Fig. 3B). Milk can coagulate by using coagulating enzymes which are naturally found in some plants (Say and Güzeler, 2016). For this purpose, in Hizan county, Pimpinella affinis Ledeb., Pimpinella kotschyana Boiss. and Arum rupicola Boiss, Cicer arietinum L., Corylus avellana L. and Triticum aestivum L. are used. In addition, ficus extract dripped into milk is used to ferment the milk. Figs contain two groups of proteolytic enzymes (Fadıloğlu, 2001; Akar and Fadıloğlu, 1999).
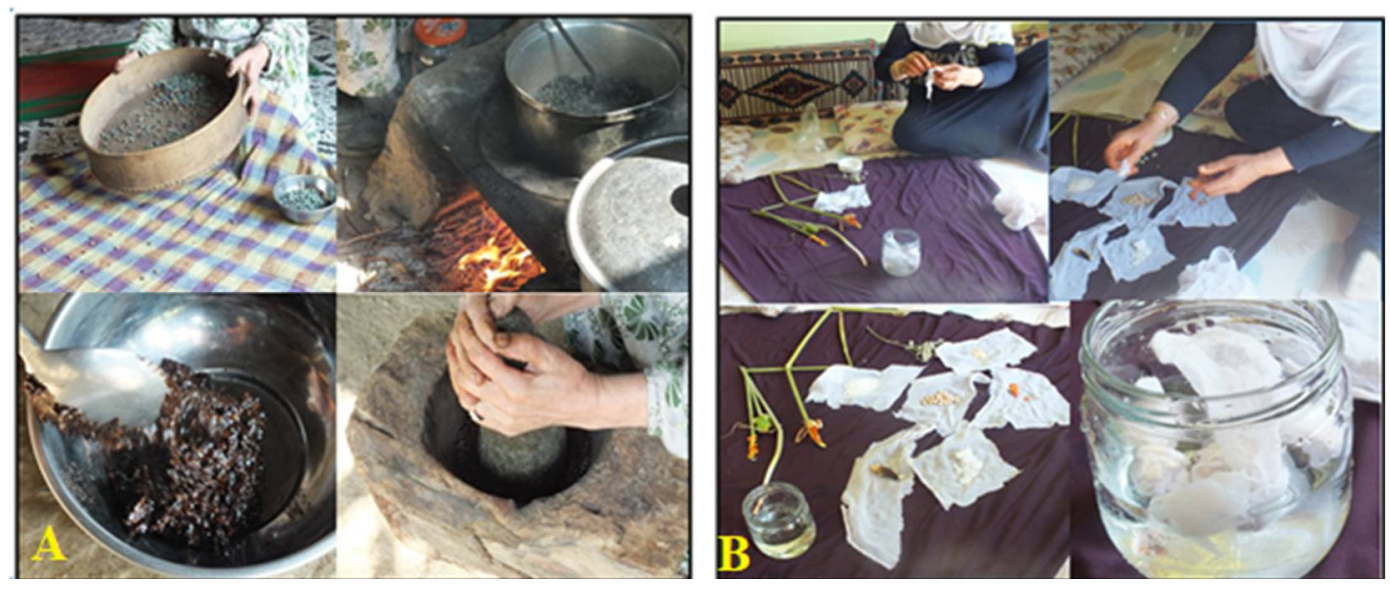

Fig. 3. A. Preparation of Bittım coffe, B. Preparation of rennet by old methods,

The consuming plants as raw (salad etc.)

Sixteen taxa assessed in this category have been identified. These plants, usually collected in spring, are consumed freshly in the form of snacks. The fresh stem of the plant Rheum ribes L. and Eryngium billardierei F. is eaten peeled. Rheum ribes is consumed too much across Eastern Anatolia (Mükemre et al., 2016; Kaval et al., 2015; Polat et al., 2015). It is also an important plant used in medicine. They are medically important due to the content of anthracene derivatives within the subterranean parts of the plants (Öztürk et al., 2007). The aerial parts of Tragopogon buphthalmoides var. latifolius Boiss., Capsella bursa-pastoris (L.) Medik., Plantago lanceolata L. and P. major L., are eaten as a snack with salt. Numerous authors claim the Plantago species can be used for human nutrition (Toussaint-Samat, 1991; Kunkel, 1983; Polunin 1977; Quer 1990).). 
Plantago species are also eaten in Anatolia especially for stomach ailments (Dalar et al., 2012). Children like and eat the sweet roots of the plant Hordeum bulbosum L. Crataegus species and Rubus idaeus L. fruits are also consumed fresh. The fresh leaves of Barbarea vulgaris R.Br., Portulaca oleracea L., Rumex scutatus L. are used in salad.

\section{Beverages}

The shelled fruits of Pistacia khinjuk Stocks plant, which is spread naturally especially on the southern sides of the county, are collected and selected. Next, it is browned in a wood fire and then crushed to make a molasses-like consistency. This beverage, called "Bittım" coffee, is consumed with and without milk as coffee (Fig. 3A). Use of this coffee is common in the areas where the plant Pistacia spreads naturally (Kaval et al., 2014; Yeşil and İnal 2019; Yeşil et al., 2019). Pistacia has been known for its medicinal properties since ancient times. They have played important roles in folk medicine and are used in eczema treatment, anti-inflammatory, stomach ache, asthma, as an antibacterial and antiviral (Tohidi et al., 2011). Rosa canina L. fruits are collected in the summer months and dried, consumed as an antitussive especially by children in winter. Thymus fedtschenkoi Ronniger and Thymus kotschyanus Boiss. \& Hohen var. glabrescens taxas, collected and dried up in the summer, are consumed as a kind of tea in winter.

The consumption as spice

Fresh leaves and shoots of Mentha longifolia (L.) Huds. subsp. longifolia, Origanum vulgare subsp. gracile (K. Koch) Ietsw., Satureja macrantha C.A. Mey., Thymus fedtschenkoi Ronniger, $T$. kotschyanus Boiss. \& Hohen var. glabrescens and Rumex crispus L. collected in the spring are dried and used as a spice to add flavor to soup and some meat dishes in the winter.

Gums

The gum is made with latex obtained from the stem of the belonged to 4 species. These are; Pistacia khinjuk Stocks, Gundelia tournefortii L., Scorzonera latifolia (Fisch. \& C.A. Mey.) and S. veratrifolia Fenzl. Gum is produced with latex obtained by scratching the trunk of the Pistacia khinjuk Stocks tree. The stems of Gundelia tournefortii L., Scorzonera latifolia (Fisch. \& C.A. Mey.) DC and S. veratrifolia Fenzl. are cut off, and their plant sap is poured on dry ground, then dried, so gum is obtained.

\section{Characteristics of participants}

Table 2 shows the demographic characteristics of participants. A total of 110 participants (62 men and 48 females) were interviewed face-to-face. The majority of the participants ( 40.0 percent) were 50 years old or older. The number of young participants was quite low (10.0 percent). This shows that traditional knowledge does not pass from the elderly to the late generations and this cultural heritage is in danger of being forgotten. Therefore, it is very important to preserve this traditional knowledge before it is lost. The majority of the participants ( 41.8 percent) were primary school graduates and illiterate (39.0 percent). The number of university graduates was almost negligible ( 3 people). All women participants are housewives (62 people) men participants are generally farmers ( 29 people).

\section{Vernacular names of plants in Hizan}

The vernacular names of plants used in Hizan are derived from Kurdish language. It has been found that the local names of some commonly used plants are almost identical to those used near the study area. For example, Rheum ribes L. (Rewas, ribez), Eryngium billardieri F. (Tüsü) and Urtica dioica L. (Gezınk, Dezınk) (Mükemre et al., 2016; Kaval et al., 2014; Kasımoğlu and Dirihi 2013). However, some locally used names are specific to Hizan, such as Amaranthus 
retroflexus L. (Tendernik), Quercus infectoria Oliv. (Berüyê hırçê) and Plantago major L. (Heyiso).

Table 2. Classification of participants according to their demographic features.

\begin{tabular}{llcc}
\hline Total people & Man/women & Number of people & Percent $(\%)$ \\
\hline Gender & Women & 62 & 56.3 \\
& Men & 48 & 43.7 \\
\hline \multirow{2}{*}{ Ages } & 30 and less than 30 & 11 & 10.0 \\
& Between 31 and 40 & 23 & 21.0 \\
& Between 41 and 50 & 32 & 29.0 \\
& Over 50 & 44 & 40.0 \\
\hline \multirow{2}{*}{ Level of education } & Illiterate & 43 & 39.0 \\
& Elemantary school & 46 & 41.8 \\
& Secondary school & 11 & 10.0 \\
& High school & 7 & 6.4 \\
& University & 3 & 2.8 \\
\hline \multirow{2}{*}{ Employment } & Farmer & 29 & 26.4 \\
& Housewife & 62 & 56.3 \\
& Others & 19 & 17.3 \\
\hline
\end{tabular}

Data analysis

Rheum ribes L. (UV: 0,70), Gundelia tournefortii L. $(0,66)$, Silene vulgaris (Moench) Garcke andRosa canina L. (0,64), Urtica dioica L. (0,63), Malva neglecta Wallr. (0,61), Pistacia khinjuk Stocks $(0,60)$, Anchusa azurea Miller. var. azurea $(0,58)$, Ferula orientalis L. and Puschkinia scilloidesAdams $(0,57)$ were reported to be of the highest use value.

This study was done to record information about plants used as food by local people living in Hizan County (Bitlis). Thus, ethnobotanical information of 65 taxa belonging to 24 families was recorded with details. In addition, participants' information was recorded. A culture of edible plant use is widespread throughout the Hizan County. However, it is understood that this culture has not been passed much to younger generations since the people giving information are generally 50 years of age or older. Young men in particular often migrate to large cities to find a job. Few numbers of young people living in the villages do not care much about this traditional knowledge. Thus, it signals that the number of people with this information is decreasing day by day and that this traditional information is in danger of disappearing. It is very important to record all ethnobotanical information from the study area as soon as possible. Therefore, this research has made an important contribution to the preservation of the cultural heritage associated with traditional wild edible plants in this region.

\section{Acknowledgement}

I thank all knowledge providers for sharing their valuable information and reviews with me, and to BEBAP [Office of Scentific Research Projects of Bitlis Eren University), Bitlis/Turkey (Projectno: 2018.07)] who supported this research financially. 


\section{References}

Akar, B. and Fadıloğlu, S. 1999. Teleme production by purified ficin. Journal of Food Quality. 22: 671-680.

Baytop, T. 1999. Therapy With Medicinal Plants in Turkey (Past and Present), Nobel Medicine Publication, Istanbul, p.13.

Bianco, V.V., Santamaria, P. and Elia, A. 1998. A. Nutritional value and nitrate content in edible wild species used in southern Italy. Proceeding 3rd IS on Diversification of Vegetable Crops. Acta Horticulture. 467: 71-87.

Çiçek, H. 2016. Bir mekân hizan: ilim ve âlim havzası. Katre Uluslararası İnsan Araştırmaları Dergisi. (1): 189-198.

Dalar, A., Türker, M. and Konczak, I. 2012. Antioxidant capacity and phenolic constituents of Malva neglecta Wallr. and Plantago lanceolata L. from Eastern Anatolia Region of Turkey. Journal of Herbal Medicine. 2(2): 42-51.

Davis, P.H. (Eds) 1965-1985. Flora of Turkey and the East Aegean Islands, Vol 1-9. Edinburgh University, Edinburgh.

Davis, P.H., Mill, R.R. and Tan, K. 1988. Flora of Turkey and the East Aegean Islands, Vol 10. Edinburgh University Press, Edinburgh.

Durmaz, H., Sagun, E., Tarakci, Z. and Özgokçe, F. 2006. Antibacterial activities of Allium vineale, Chaerophyllum macropodum and Prangos ferulacea. African Journal of Biotechnology. 5(19): 17951798.

Fadıloğlu, S. 2001. Immobilization and characterization of ficin Nahrung Food. 45(2):143-146.

Font Quer, P. 1990. Plantas Medicinales. El Dioscórides renovado. Labor, Barcelona. p. 724-725.

Green, C. 1992. An overview of production and supply trends in the U.S. specialty vegetable market. Acta Horticulture, 318: 41-45.

Güner, A. Özhatay, N. Ekim, T. and Başer, K.H.C. 2000. Flora of Turkey and the East Aegean Islands, Vol 11. Edinburgh: Edinburgh University Press.

Henry, A.G., Brooks, A.S. and Piperno, D.R. 2011. Microfossils in calculus demonstrate consumption of plants and cooked foods in Neanderthal diets (Shanidar III, Iraq; Spy I and II, Belgium).Proceedings of the National Academy of Sciences. 108(2): 486-491.

Kasimoğlu, A. and Dirihî, E. 2013. Ferhenga Navên Nebatan A Kurdî. Kürtçe Bitki Adları Sözlüğü. Birinci Baskı: Istanbul.

Kaval, İ., Behçet, L. and Çakılcıŏlu, U. 2015. Survey of wild food plants for human consumption in Geçitli (Hakkâri/Turkey), Indian Journal of Traditional Knowledge. 14(2): 183-190.

Kılıç, O., Kutlu, M.A. and Özdemir, F.A. 2016. Pollen analysis of honey from the hizan district of bitlis province, eastern region of turkey. Int J Plant Anim Environ Sci. 6(1): 1-9.

Kunkel, G. 1983. Malas hierbas de Almería. Cajal, Almería. p.122-125.

Madella, M., Jones, M.K., Goldberg, P., Goren, Y. and Hovers, E. 2002. The exploitation of plant resources by Neanderthals in Amud Cave (Israel): the evidence from phytolith studies. Journal of Archaeological Science. 29(7): 703-719.

Mükemre, M., Behçet, L. and Çakılcıŏlu, U. 2016. Survey of wild food plants for human consumption in villages of Çatak (VanTurkey), Indian Journal of Traditional Knowledge. 15 (2): 181-191.

Nesbitt, M. 1995. Plants and people in ancient Anatolia. The Biblical Archaeologist. 58(2): 68-81.

Özçelik, H. 1994. On the herbal cheese from East Anatolia (Turkey), Economic Botany. 48(2): 214-217.

Öztürk, M., Aydoğmuş, F., Duru, M.E. and Topçu, G. 2007. Antioxidant activity of stem and root extracts of Rhubarb (Rheum ribes): An edible medicinal plant. Food chemistry. 103(2): 623-630.

Phillips, O. L. and A. H. Gentry. 1993. The useful plants of Tambopata, Peru: I. Statistical hypothesis tests with a new quantitative technique. Economic Botany 47(1):15-32.

Plant List2013 <www.theplantlist.org>. Retrieved on 12 November 2019.

Polat, R., Çakılcıŏlu, U., Ulusan, M.D. and Paksoy, M.Y. 2015. Survey of wild food plants for human consumption in Elazığ (Turkey), Indian Journal of Traditional Knowledge, 1(1): 69-75. 
Polat, R., Güne, B., Yüce-Babacan, E. and Çakılcıŏlu, U. 2017. Survey of wild food plants for human consumption in Bingöl (Turkey), Indian Journal of Traditional Knowledge. 16(3): 378-384.

Polunin, O. 1977. Guía de campo de las flores de Europa. Omega, Barcelona. pp. 467.

Sánchez-Monge, E. 1980. Diccionario de Plantas Agrícolas. Ministerio de Agricultura, Madrid.

Say, D. and Güzeler, N. 2016. Production of Traditional Cheese Coagulant in Farmhouse and Coagulating Effect. Current Research in Nutrition and Food Science. 1: 133-137.

Tepe, I. 2014. Yabancı Otlarla Mücadele. Sidas Medya, İzmir. pp. 201-2015.

Tohidi, M., Khayami, M., Nejati, V. and Meftahizade, H. 2011. Evaluation of antibacterial activity and wound healing of Pistacia atlantica and Pistacia khinjuk. Journal of Medicinal Plants Research. 5(17): 4310-4314.

Toussaint-Samat, M. 1991. Historia natural y moral de los alimentos. Alianza Editorial, Madrid.

Turan, M., Kordali, S., Zengin, H., Dursun, A. and Sezen, Y. 2003. Macro and micro mineral content of some wild edible leaves consumed in Eastern Anatolia. Acta Agriculturae Scandinavica, Section B-Plant Soil Science. 53:3129-137.

Urhan, Y., Ege, M.A., Öztürk, B. and Elgin Cebe, G. 2016. Turkish food plants database. Journal of Faculty of Pharmacy of Ankara University. 40(2): 43-57.

Yeşil, Y. and İnal, İ. 2019. Traditional knowledge of wild edible plants in Hasankeyf (Batman Province, Turkey). Acta Soc Bot Pol. 88: 3633.

Yeşil, Y., Çelik, M. and Yılmaz, B. 2019. Wild edible plants in Yeşilli (Mardin-Turkey), a multicultural area. Journal of Ethnobiology and Ethnomedicine. 15(1): 52.

(Manuscript received on 28 February, 2020; revsied on 13 November, 2020) 